\title{
ПЕРЕЖИВАННЯ ЕМОЦЙНОГО ВИГОРАННЯ ТА ДЕПРЕСІЇ У СТУДЕНТСЬКОМУ ВІЦІ
}

УДК: $316.62: 613.86$

\section{Проскурняк Ольга Петрівна \\ Кандидат психологічних наук, доиент кафедри психології Чернівецького національного універси- тету імені Юрія Федьковича, м. Чернівці (Україна)}

\section{Чаплак Ян Васильович}

Кандидат психологічних наук, доцент кафедри психології Чернівецького національного університету імені Юрія Федьковича, м. Чернівизі (Украӥна)

\section{Чуйко Галина Василівна}

Кандидат філологічних наук, дочент кафедри психологіі Чернівецького національного університету імені Юрія Федьковича, м. Чернівиі (Україна)

Аннотация. Стаття пов'язана з теоретичним аналізом та емпіричним дослідженням емоційного вигорання та депресивного стану у студентів-психологів.

Схарактеризовані основні симптоми, причини $і$ фактори розвитку даних афективних проявів; зазначено, щзо їх основною причиною науковцฺі вважають тривалий стрес чи вплив на людину психотравмуючих ситуацій.

Зроблено висновок, що між вигоранням $і$ переживанням реактивної депресії існують відмінності, щзо, незважаючи на можливість одночасного прояву емочійного вигорання та депресивного стану в людини, причиново-наслідковий зв'язок між ичими феноменами не виявлений.

Ключевъе слова: вигорання, реактивна депресія, стрес, емоційне виснаження, деперсоналізація, редукиія персональних досягнень.

Постановка проблеми. У наш час депресія зустрічається так само часто, як вигорання (оскільки у житті людини ситуацій і подій, які вона може сприйняти як психотравмуючі чи катастрофічно-незворотні, не менше, ніж стресфакторів у будь-якій професійній діяльності), хоча причини та наслідки їх зазвичай різні (але, можуть виявитися однаково важкими), а реальний зв'язок частіше відсутній. Проте, схожість проявів і симптомів цих 
феноменів, розуміння їх як стрес-реакції, їх належність до афективних порушень і те, що вони можуть зустрічатися у людини в той самий час, зумовлює цікавість до характеру зв'язку між ними.

Аналіз досліджень і публікацій. 3 часу появи феномену вигорання у психології його дослідження стало популярним і продовжується дотепер. Так, до вивчення проблеми зверталися такі вчені: К. Маслач, С. Джексон, В. В. Бойко, Н. В. Самоукіна, П. І. Сидоров, О. Н. Доценко, Т. В. Форманюк, В. О. Орел, А. Ленгле, М. В. Борисова, I. Калашник, Т. В. Рябова, Н. С. Водоп'янова та ін. Не меншу цікавість у вчених викликає i переживання депресивного стану, аналіз якого здійснювали А. Бек, В. А. Жмуров, Е. Соломон, Н. В. Полєнова, В. Л. Мінутко, Д. Холл, С. Салманс та ін.

Та, не дивлячись на велику кількість наукових робіт, присвячених аналізу феномену вигорання, досі це поняття не має загальноприйнятого визначення, про що свідчить, зокрема, те, що вчені використовують його як самостійне, так і в поєднанні з визначеннями «емоційне», «професійне» чи «психічне», не ставлячи завдання розрізнити їх. Щодо феномену реактивної депресії, зазначимо, що навіть за умови, що наукових робіт, присвячених розгляду депресії у психології та медицині, величезна кількість (що, власне, відображає поширеність цього захворювання), вони надзвичайно рідко стосуються порівняльного аналізу проявів депресивного стану та емоційного вигорання особистості.

Мета статті - теоретично та емпірично вивчити і проаналізувати феномени емоційного вигорання та реактивної депресії і можливий взаємозв'язок між ними.

Виклад основного матеріалу. Добре відомо, що термін burnout, що відповідає психічному вигоранню, введений у психологію в 1974 р. Г. Дж. Фрейденбергером, проте це поняття почали вживати ще до того, як ним зацікавилися психологи. Фрейденбергер започаткував наукове використання поняття вигорання першим, описуючи поступове емоційне спустошення, втрату мотивації та прихильності (довіри) до робочих зобов'язань серед волонтерів клініки для наркозалежних і безхатченків та виходячи 3 власного досвіду [15, c. 205].

Майже у той же час і незалежно від нього К. Маслач 3 колегами «вийшла» на цей термін, проводячи інтерв'ю $з$ працівниками сфери обслуговування, виясняючи, до яких захисних механізмів вони вдаються, намагаючись впоратися 3 емоційним перевантаженням. Учена виявила, що ці службовці переживають емоційне виснаження, у них розвивається негативне ставлення до клієнтів, вони почуваються професійно некомпетентними у результаті емоційного сум'яття і називають свій стан вигоранням [15, с.205-206]. Маслач розуміла вигорання як багатовимірну конструкцію: «вигорання - це синдром емо- 
ційного виснаження, деперсоналізації та редукції персональних досягнень, що може зустрітися серед тих, хто працює 3 людьми у певній якості» $[15$, с.214; 12]. А для професіонала, який постійно стикається 3 важкими ситуаціями, в яких вирішення проблем клієнтів $€$ неочевидним і нелегким, «хронічний стрес може бути емоційно виснажливим і привести до вигорання» [12, с. 192]. Проте з часом було виявлено, що вигорання може торкнутися i представників інших професій, що відобразилося на визначенні поняття як «стану виснаження, в якому особа є цинічною по відношенню до цінності власного заняття і сумнівається у своїй здатності виконувати» професійні обов'язки [15, с. 206].

К. Маслач описала емоційне вигорання як мультифакторний синдром, ключовим аспектом якого є зростання почуття емоційного виснаження; оскільки емоційні ресурси спустошуються, працівники відчувають, що вони не можуть більше віддавати себе роботі на потрібному психологічному рівні [13, с. 399]. Другий симптом вигорання - розвиток деперсоналізації (негативних, цинічних установок і почуттів стосовно клієнтів). Маслач зазначає, що таке безсердечне і навіть дегуманізоване сприйняття інших може привести персонал до бачення клієнтів як таких, що певною мірою заслужили свої проблеми [12, с. 192]. Третій аспект синдрому вигорання, зменшення особистих досягнень, стосується тенденції оцінювати себе негативно, особливо з урахуван- ням роботи 3 клієнтами. Працівники можуть почуватися нещасними і незадоволеними своїми досягненнями в професії.

Згідно В. О. Орела, «вигорання може бути розглянуте як розтягнутий у часі професійний стрес, коли вимоги роботи переважать реальні можливості працівника», проте вчений виділяв такі відмінності між цими процесами, як тривалість, особливості впливу на поведінку професіонала і ступінь поширення: якщо стрес - це адаптаційний синдром, то вигорання - зрив у адаптації; стрес може не погіршувати ефективність професійної діяльності, й не кожний стрес провокує вигорання [5, с. 133]. Крім того, В. О. Орел висловив слушну думку, що розгляд вигорання як «атрибуту діяльності людини» приводить до «теоретичної можливості існування вигорання і в інших іiї видах, наприклад, в навчально-професійній діяльності» [5, с. 38].

На думку А. Ленгле, вигорання, яке він тлумачить як «затяжний стан виснаження, що виникає в діяльності» [2, с. 5] і поступово охоплює не лише емоції, але й установки, рішення та дії людини, пов'язане з трьома вимірами людського буття (за В. Франклом): фізичним (соматичним), психічним і ноетичним. I оскільки в емоційному вигоранні присутні обидва основні симптоми екзистенційного вакууму: відчуття порожнечі, яке супроводжується наростаючим почуттям втрати духовних орієнтирів, та відчуття безглуздості, яке поширюється на все більше число аспектів життя лю- 
дини, в результаті чого вже саме життя переживається як безглузде, - його можна було б позначити, за А. Ленгле, як особливу форму екзистенційного вакууму, в якій, однак, домінує картина виснаження [2].

Пізніше (після К. Маслач) Г. Сонех додав до симптомів вигорання «вітальну нестабільність», разом 3 яким це $\epsilon$ ознакою «розвитку предсуїцидального стану». Сонех наводить такі симптоми вітальної нестабільності: депресія, подавлений настрій, збудливість, почуття важкості, тривожність, неспокій, почуття безнадії та дратівливість. Емоційне вигорання, на думку вченого, являє собою реальну специфічну загрозу здоров'ю [2, с. 4].

Н. В. Самоукіна симптоми, що складають синдром емоційного вигорання, ділить на три групи: психофізичні симптоми, серед яких: почуття постійної втоми, емоційного та фізичного виснаження, зниження сприйнятливості подій, загальна астенізація, порушення в діяльності різних органів та систем, безсоння та загальмованість, зниження сенсорної чутливості; соціально-психологічні симптоми байдужість, нудьга, депресія, дратівливість і нервові зриви без явних приводів, постійне переживання негативних емоцій, почуття неспокою, страху, надмірної відповідальності, негативна установка щодо життєвих і професійних перспектив; поведінкові - відчуття, що роботу стає все важче виконувати, змінюється робочий режим дня, керівник втрачає здатність вирішувати, а робітник - ефективно пра- цювати, з'являються відчуття непотрібності, байдужість до результатів, «застрягання» на деталях, витрата робочого часу на виконання автоматичних дій, через що робота береться додому, проте, зазвичай не виконується [9].

К. Маслач і М. Лейтер створили модель вигорання, що зосереджується на ступені відповідності (невідповідності) між людиною та шістьма сферами її робочого оточення. Чим більша невідповідність між ними існує (а вона відображається на ставленні до роботи, «психологічному контакті» 3 нею), тим вірогіднішим стає вигорання, чим більше людина підходить за своїми якостями для виконання певної діяльності, тим більша ймовірність залучення її до діяльності, взаємодія з нею. Отже, модель упорядковує ситуаційні фактори вигорання, пропонуючи шість складових професійної зайнятості, які охоплюють основні причини вигорання: робоче навантаження, контроль, винагорода, громада, справедливість і цінності [13, с. 413]. Емоційне вигорання виникає внаслідок тривалих розбіжностей між людиною та іiї роботою у кількох чи усіх шести організаційних факторах діяльності, які можуть стати передумовами вигорання: 1) робоче навантаження: надмірні вимоги вичерпують енергію особистості так, що вона не встигає відновитися, як і невідповідність вимог діяльності здібностям особистості; 2) контроль - надмірна відповідальність за результат роботи контрастує з некомпетентністю людини у відповідній сфері діяльності, і людина 
нездатна контролювати свої сили, що витрачаються на виконання роботи; 3) винагорода (оплата): брак гідної винагороди за зроблене та досягнуте (фінансової, соціальної, психологічної, позитивної оцінки, визнання) приводить до появи почуття неефективності діяльності; 4) громада (співробітники) - втрата позитивного почуття зв'язку з колегами, можливості спілкуватися 3 ними та ділитися емоціями, брак соціальної підтримки, різні цінності, - усе це може спровокувати міжособистісні конфлікти; 5) справедливість, яка збільшує самоповагу і самооцінку особистості: відсутність справедливих стосунків на робочому місці - серйозна причина вигорання; несправедливість може стосуватися навантаження чи оплати праці, позбавлення можливості відстояти себе. Це емоційно виснажує і формує цинічне ставлення до роботи; 6) цінності: конфлікт між особистими й організаційними цінностями та принципами (тим, що вимагає робота i тим, що людина вважає цінним (моральним)). Саме вимір цінностей, на думку вчених, може відігравати основну роль у провокуванні вигорання, хоча все залежить від того, якому $з$ шести факторів людина надає найбільше значення та скільки вона може витерпіти цю невідповідність за рахунок іiі компенсування позитивом іншого фактора. Ці критичні фактори складають основу кризи порушення стосунків людини 3 іï роботою (людина в контексті їі діяльності) [13].

В. В. Бойко визначає емоційне вигоран- ня як вироблений особистістю механізм психологічного захисту, що полягає у повному або частковому виключенні емоцій у відповідь на певні психотравмуючі впливи. Вчений описує процес розвитку емоційного вигорання аналогічно до структури стресу (за концепцією Г. Сельє): фаза «напруги» (переживання психотравмуючих обставин; незадоволеність собою; відчуття «загнаності в клітку»; тривога і депресія), «резистенції» (неадекватне емоційне вибіркове реагування; емоційноморальна дезорієнтація; розширення сфери економії емоцій; редукція професійних обов'язків) i «виснаження» (емоційний дефіцит; емоційна відстороненість; особистісна відстороненість (деперсоналізація); психосоматичні та психовегетативні порушення) [3]; очевидно, що лише остання фаза стресу відповідає емоційному вигоранню.

Цікавим, хоча й неоднозначним, є погляд на вигорання Д. Г. Трунова, який пропонує «поглянути на так званий «синдром згорання» як на природ-ний і нормальний процес»» [11], мотивуючи тим, що «ненормальним є не те, що людина, яка працює у сфері психологічної допомоги, «згорає», а той випадок, коли вона не «згорає»»». Він намагається довести, що до симптомів вигорання варто ставитися позитивно, як до сигналів «внутрішньої сфери», що по-трапляють у сферу свідомого, повідомляючи людині, що з нею відбувається, сигналізують про «проблеми, що наближаються» [10]. 
Вчений підсумовує, що позитивне ставлення до симптомів вигорання допоможе людині прийняти важливу інформацію про себе, що до цього була «за кадром» [10].

На нашу думку, людина, яка у професійній діяльності віддає себе іншим і бачить у цьому сенс свого життя, повністю включається у свою роботу і не може не горіти i, відповідно, не вигорати; вона просто не має такого вибору. I горіння - це синонім захоплення професією. Та, на думку Трунова, людина має горіти не лише в професії, але й повсякденно, у житті, це природно і нормально [11]. Насправді ж, у наш час справжні ентузіасти, які реалізують своє покликання і життєвий сенс у професії, зустрічаються так само рідко, як і людина, яка постійно щиро захоплюється процесом життя, - ми б назвали таку людину наївним оптимістом і поспівчували б їй: сучасний світ на це зовсім не розрахований, і такі почуття і ставлення, скоріше, виглядають оригінально-дивними, ніж природними. Що ж до «глобальних сенсів людського існування» (за Труновим, таким є «горіння» людини), варто пригадати думку В. Франкла, що сенси не просто індивідуальні для кожної людини (а не «глобальні»), але й для кожної окремої життєвої ситуації.

При цьому ми не заперечуємо (не спростовуємо думку вченого), що справжній спеціаліст у своїй галузі має «горіти» на роботі (найповніше реалізувати свої здібності і можливості, якщо бачить у цьому справжній сенс свого існування), принаймні, проявляти професійну порядність: максимально якісно виконувати свої професійні обов'язки, щоб відчувати задоволення від процесу і результату своєї роботи (але не «згорати» дотла на робочому місці).

Варто зазначити, що серед величезної кількості характеристик процесу емоційного вигорання переживанню депресії науковці приділяли особливу увагу, намагаючись відповісти на питання, чи впливає вигорання на депресію, тим самим визначаючи це поняття, чи навпаки. Дослідження продемонстрували різницю між цими феноменами: вигорання пов'язане з роботою і специфічною ситуацією, тоді як депресія $є$ більш загальним поняттям, вільним від конкретного контексту, хоча у подальшому дослідженні стверджувалося, що за умови високих рівнів прояву ці стани важко розрізнити [14].

На нашу думку, цю проблему породила відсутність реальної згоди між науковцями у тлумаченні як феномену вигорання, яке могло розумітися як переживання стресового стану, що завершується тяжким дистресом 3 відповідними наслідками чи як кінцевий етап процесу виснаження (та нерозрізненні понять «емоційне» та «професійне» вигорання), так і депресії (яку дослідники вигорання намагаються пояснити саме як реактивну депресію (емоційний стан), «забуваючи» про ії психіатричну багатовимірність). У цьому смислі, якщо виходити 3 тлумачення вигорання 
К. Маслач, а реактивної депресії - як відносно скороминучого емоційного стану, що «накриває» особу після іï раптової зустрічі 3 психотравмуючою ситуацією значної сили чи тривалості, виявляються очевидні відмінності між цими поняттями, навіть 3 позиції, що вигорання і депресія $є$ наслідками (результатом) стресу: 1) вигорання - результат тривалої дії стресового фактора; депресивна реакція може виникнути і внаслідок одноразового впливу стресової ситуації; 2) як зазначено вище, вигорання прямо пов'язане з професійною діяльністю та виконанням професійних обов'язків, тоді як у депресії такий зв'язок відсутній, вона у цьому сенсі універсальна і може виникнути практично у будь-якій ситуації (а заняття будь-якою (i професійною) діяльністю «притупляє» переживання депресіі); 3) нарешті, навіть у випадку існування зв'язку між вигоранням і депресією він не $\epsilon$ загальним i обов'язковим: у деяких випадках переживання ситуації професійного вигорання може супроводжуватися депресивними симптомами (причому, передбачаємо, що не завжди це стан реактивної депресії), але - далеко не у всіх професіоналів, які переживають вигорання: люди дуже різні, і на появу чи відсутність симптомів депресії впливає не тільки (не стільки) вигорання, але й індивідуальні особливості особистості. Що ж до схожості проявів вигорання та депресії на високих рівнях [14] - ситуація сумнівна: варто лише згадати, що високий рівень переживання депресії межує 3 па- тологічною формою складного захворювання (з відповідними симптомами), тоді як вигорання у більшості випадків до психопатології не веде. Хоча існування складного і неоднозначного зв'язку між вигоранням і депресією важно заперечити, що може пояснюватися фактом, на якому наголошують медики, вносячи ці феномени до міжнародної класифікації захворювань: обидва процеси представляють собою реакцію на дію стресу, і не важко помітити схожість в описі депресивного стану та переживання людиною емоційного вигорання.

Найчастіше, як на нас, зустрічається реактивна депресія, що може з'явитися як реакція на психотравмуючу ситуацію [4], наприклад, утрати (уявної чи реальної) людною того, що вона вважає життєво важливим (екзистенційною цінністю). Саме тому реактивну депресію супроводжує відчуття втрати i цілий спектр негативних суб'єктивних переживань, ним зумовлених (гнів, страх, смуток, печаль, самозвинувачення, безпорадність, неможливість вирішувати, ін.) [6]. Іноді до них приєднується відчуття відчаю і безнадії, і людині здається, що життя не просто не повернеться до того, що було, але й взагалі ніколи вже не стане нормальним, не буде нічого доброго і світлого, при цьому людина може усвідомлювати, що іiї стан - реакція на конкретну жи-ттєву ситуацію. І якщо спочатку він може приховуватися від оточуючих, то 3 часом, 3 поглибленням переживання депресії, він може реалізуватися через відповідну поведінку, ког- 
нітивні та фізичні (соматичні) симптоми [6;8]. Особа у поганому настрої і стані безнадії знаходиться постійно, відсторонена від людей $\mathrm{i}$ подій, редукуються професійні обов'язки, людина не має сили докладати зусилля ні до чого, прагне заховатися від усього у власній мушлі. Інтереси людини обертаються навколо психотравмуючої події, вона знову і знову переживається (свідомість зосереджується на події, що сталася).

При цьому зміни торкаються апетиту i сну, з'являються різні скарги на порушення у самопочутті, ніяк не підтверджені фізично. Навіть радісні події зустрічаються зі значною часткою недовіри і скептицизму, песимізмом, як такі, що нічого не здатні змінити на краще. До будь-якої події така особа підходить з позиції того, наскільки погано вона може закінчитися і які нещастя принести. Людина втрачає не лише об'єктивність в оцінці ситуації, вона може втратити відчуття реальності, занурившись у внутрішній світ самозвинувачення, трактуючи свій стан як покарання як власну відповідальність через нездатність відвернути подію чи розвиток ситуації, що привела до депресивного стану. Проте, у випадку реактивної депресії людина цілком усвідомлює свій стан, намагаючись справитися з його наслідками, розуміючи незмінність його причини, тому реактивна депресія триває зазвичай не дуже довго, їі симптоми поступово, 3 часом, зникають, не досягаючи крайніх (патологічних) проявів [8]. За суттю, реактив- на депресія є специфічною реакцією людини на стрес і визначається їі вразливістю і низькою стресостійкістю.

Згідно психологічного словника, депресія (від лат. depression - подавлення) - афективний стан, що характеризується негативним емоційним фоном, зміною мотиваційної сфери, когнітивних (пов'язаних з пізнанням) уявлень і загальною пасивністю поведінки. Переживання реактивної депресії може спричинити гострий інтенсивний психологічний стрес чи дистрес, який не є інтенсивним, але впливає тривалий час, тобто ситуаціями, до подолання яких людина через різні причини виявилася непідготовленою [1, с. 84]. Отже, депресивний стан розвивається після того, як у житті людини відбулася катастрофічна подія значної (глобальної) сили чи «ряд таких ситуацій, які вона сприйняла як негативні», але те, наскільки травмуючою для психіки людини була подія, визначається особливостями її суб'єктивного сприйняття [6].

Від інших негативних емоційних станів реактивну депресію відрізняють такі ознаки: зміни емоційного стану відбуваються внаслідок (після) ситуації, що сприймається людиною як катастрофічна, за причинно-наслідковим зв'язком, і «психоемоційні реакції та зміни в поведінці перевищують значимість події i/чи їх тривалість перевищує тривалість нормальних реакцій» [6].

Депресивна реакція може бути короткою (до 1 місяця) та пролонгованою (до 2-х 
років). Короткочасна депресія безпосередньо пов'язана 3 пережитим нещастям, що сягає величини катастрофи і виконує роль психотравми у сприйнятті людини. Пролонгована депресивна реакція пов'язана 3 тривалою дією стресфакторів - дистресом. Події у цьому випадку не сприймаються як тотальна криза, однак хронічний стрес пов'язаний $з$ постійним емоційним напруженням, яке трансформується в апатію, виснаженість [4; 7].

По суті, реактивну депресію можуть викликати різні ситуації, що різко порушують плин життя людини, руйнують іiі життєві цілі, цінності та сенс, є особистісно значимими.

Одним 3 факторів ризику виникнення депресивної реакції є професійна належність людини. Так, для осіб, які через свою професію змушені отримувати надмірні психічні навантаження чи відчуття відповідальності за здоров'я чи життя інших людей (за суттю, це представники професій типу «людина - людина», як і у випадку емоційного вигорання), стреси стають «звичними», так що реакція на них зовні не проявляється, тоді як під «маскою» спокою приховується кипіння емоцій, що з часом неминуче приводить до проблем 3 психікою та нервовою системою, які можуть «вилитися» у реактивну депресію [6].

Для перевірки взаємозв'язку між депресією і вигоранням нами проводилося дослідження, у якому використовувалися методики: МВI (К. Маслач і С. Джексон; адаптований Н.С. Водоп'яновою), діагностики рівня емоційного вигорання В. В. Бойко; опитувальник депресії А. Бека; тест «Індекс життєвої задоволеності» (ІЖЗ), адаптація Н. В. Паніної; опитувальник «Втрати і надбання персональних ресурсів» (Н. Водоп'янова, М. Штейн); опитувальник самоставлення (В. В. Століна, Р. С. Пантілєєва); Фрайбурзький особистісний опитувальник (FPI); для визначення рівня суб'єктивного контролю (РСК) Дж. Роттера (адаптація Є. Ф. Бажина, С. А. Голинкіної, А. М. Еткінда). Вибірку склали 48 майбутніх психологів - студентів ЧНУ ім. Ю.Федьковича.

Аналіз отриманих результатів засвідчує:

- у значної кількості опитаних - 36,73 \% депресивний стан відсутній; у 34,69 \% досліджуваних виявлено легкий ступінь переживання депресії, у 4,08 \% - помірний; по 12,24 \% студентів переживають депресивний стан середнього і високого рівня;

сильніше за інші у вибірці представлені такі особистісні характеристики, як відкритість (середня - 77,7 \% від максимального показника), врівноваженість $(54,5 \%)$, екстравертованість $(51,7 \%)$ i дратівливість (51,56 \%); менше за решту проявляються невротичність (середня $41,9 \%)$, спонтанна $(40,7 \%)$ та реактивна агресивність $(38,4 \%)$;

середня загального самоставлення по вибірці складає 20,08 балів (90,67 \% на- 
коплених частот), що свідчить про в цілому сформоване ставлення опитуваних до себе; серед складових самоставлення переважають глобальне самоставлення і очікуване ставлення від інших (середні по 71,33 \%), тоді як найменше проявляється автосимпатія (39,67 \%), цілком сформована лише у 53,06 \% опитаних; серед поведінкових проявів самоставлення інші переважають показники самоприйняття (середня - 70,67 \%), самовпевненості $(65,67 \%)$ та саморозуміння $(68,67 \%)$, тоді як найменше студенти схильні до самозвинувачення (43,33 \%);

- $\quad 46,94$ \% студентів виявили низький рівень задоволеності життям; у 20,41 \% опитаних цей показник на високому, в решти - на середньому рівні; серед складових життєвої задоволеності переважає послідовність (стійкість, наполегливість) у досягненні поставлених цілей (середня - 5,55 балів) та переважно позитивний фон настрою (5,04 балів);

- у вибірці частіше проявляється середній індекс ресурсності (у 42,86 \% опитаних), ще у $32,65 \%$ студентів - високий, тобто вони можуть добре адаптуватися i $\epsilon$ стресостійкими, у решти, 24,49 \%, - низький; за середніми, рівень здобутків (84,92 балів) дещо переважає показник втрат персональних ресурсів $(78,88$ балів);

- $\quad$ за методикою К. Маслач, деперсоналіза- ція проявляється сильніше від решти складових вигорання: по 41,67 \% студентів-психологів мають високий і середній рівні цього показника; показник емоційного виснаження на високому та середньому рівнях проявляється у 14,58 \% та 62,5 \% опитаних; практично нерозвинутою у вибірці $є$ третя складова вигорання: редукція професійних обов'язків (що закономірно, з огляду на особливість вибірки);

за методикою В. В. Бойко, більше за інші симптоми стресу, що може спричинити емоційне вигорання, проявляється напруга: у 25 \% опитаних - високий, у 41,67 \% - середній рівень прояву показника; два інші симптоми вигорання розвинуті менше: опору - переважно на середньому рівні прояву (у 62,5 \% опитаних), виснаження - на низькому (у $52,08 \%$ студентів); серед складових симптому напруги сильніші прояви невдоволеності собою, тривоги i депресії: по $33,33 \%$ осіб із середнім і по $25 \%$ - 3 високим рівнем прояву симптомів, хоча й інші показники цього симптому вигорання достатньо пропорційно розвинені; у фазі опору домінує показник неадекватного емоційного вибіркового реагування: високий рівень показника - у 62,5 \% опитаних; з показників симптому виснаження таким є показник емоційного дефіциту (високий рівень діагностовано у 


\section{$37,5 \%$ студентів);}

- отже, у майбутніх психологів синдром емоційного вигорання починає формуватися, вони частіше схильні до незадоволення собою, своїми спілкуванням і діями, тривоги i депресії в результаті сприйняття багатьох ситуацій як стресових і браку позитивних емоцій;

- $\quad$ у вибірці переважає інтернальний рівень суб'єктивного контролю, причому в $25 \%$ опитаних - високий, у $75 \%$ - cepeдній рівень прояву інтернальності.

Проведений нами кореляційний аналіз за результатами дослідження свідчить: людина, яка переживає в тій чи іншій мірі стан реактивної депресії, може перебувати у стані емоційного вигорання (зокрема, переживати емоційне виснаження $(\mathrm{r}=0,67)$ та розвиток деперсоналізації $(\mathrm{r}=0,59)$, їх симптоми чи (розуміючи вигорання як результат стресового стану, що проходить відповідно до його структури (В. В. Бойко)), знаходитись на стадії опору $(\mathrm{r}=0,73)$ чи виснаження $(\mathrm{r}=0,56)$, а соматичні ознаки депресивного стану пов'язані зі стадією «напруги» $((\mathrm{r}=0,31)$ та іï симптомом - «незадоволеність собою» $(\mathrm{r}=0,38))$, проте це не $\epsilon$ свідченням причиннонаслідкового зв'язку між ними, а лише схожості в перебігу станів.

Висновки. 1. Вигорання та реактивна депресія $є$ достатньо грунтовно і різнобічно дослідженими феноменами, що, однак, досі не привело до систематизації уявлення про них у психології. 2. Одночасний прояв у людини емоційного вигорання і депресивного стану не свідчить про наявність причино-наслідкового зв'язку між ними. 3. Студент, який опинився у ситуації переживання емоційного вигорання та/чи депресивного стану, частіше володіє особистісними характеристиками депресивності, відкритості та емоційної лабільності з переважанням жіночих рис, тоді як риси врівноваженості, товариськості чи невротичності у нього не виражені; його загальне самоставлення недостатньо сформоване в цілому та у своїх складових і поведінкових проявах, він виявляється схильним до самозвинувачення, має проблеми з очікуваним і реалізованим ставленням від інших, саморозумінням, упевненістю в собі, прийняттям себе, самоповагою і автосимпатією. У такої людини переважає екстернальний локус контролю загальний та у досягненнях, стосунках у сім’ї та навчанні, у ставленні до здоров'я; вона не почувається задоволеною життям (і благополучною) як у цілому, так і в різних його аспектах, особливо у постановці гідної мети, узгодженості між поставленими і досягнутими цілями, негативному фоні настрою; оцінюючи своє життя, вважає, що втрати переважають здобутки, i зосереджується на переживанні втрат життєвих ресурсів.

Перспективу подальших досліджень проблеми переживання емоційного вигорання та депресії вбачаємо у розробці методів їх профілактики та подолання у руслі позитивної 


\section{психології.}

\section{Перелік використаних джерел:}

1. Краткий психологический словарь / Под общ. ред. А.В. Петровского, М.Г. Ярошевского; Ред.-сост. Л.А. Карпенко. - Ростов н/Д : Феникс, 1999. - 505 с.

2. Лэнгле А. Эмоциональное выгорание с позиции экзистенциального анализа / А. Лэнгле // Вопросы психологии. -2008 . - № 2. - С.3-16.

3. Методика диагностики уровня эмоционального выгорания В.В. Бойко [Электронный ресурс]. - Режим доступа: http://psylist.net/praktikum/19.htm.

4. Минутко В. Л. Реактивная депрессия [Электронный pecypc] / В.Л. Минутко. - Режим доступа: http:// www.depressia.com/depressiya/reaktivnaya-depressiya.

5. Орел В. Е. Синдром психического выгорания. Мифы и реальность / В.Е. Орел. - Х.: Гуманитарный центр, 2014. - 296 c.

6. Поленова Н. В. Реактивная депрессия: причины, симптомы и лечение этой болезни [Электронный ресурс] / Н.В. Поленова. - Режим доступа: http://depressio.ru/ nastroenie/14-reaktivnaya-depressiya.html.

7. Реактивная депрессия // Энциклопедический словарь по психологии и педагогике. 2013 [Электронный реcypc]. - - Режим доступа: http:// psychology_pedagogy.academic.ru/14613/

Реактивная_депрессия.

8. Реактивная депрессия [Электронный ресурс]. - Режим доступа: // http://depressia.info/vidy-depressiy/ reaktivnaya-depressiya/.

9. Самоукина Н. В. Синдром профессионального выгорания / Н.В. Самоукина // Медицинская газета. - 2005. - № 43. -8 июля. - С.21-22.

10. Трунов Д. Г. «Синдром сгорания»: позитивный подход к проблеме / Д.Г. Трунов // Журнал практического психолога. - 1998. - № 8. - С.84-89.

11. Трунов Д. Г. Еще раз о «синдроме сгорания»: экзистенциальный подход [Электронный ресурс] / Д.Г. Тру- нов. - Режим доступа: http://hpsy.ru/public/x833.htm.

12. Maslach C. Maslach burnout inventory manual / C.Maslach, S.E. Jackson, M.P. Leiter // Zalaquett C.P., Wood R.J. Evaluating stress: a book of resources. Lanham, Maryland: Scarecrow Press, 1997. - Pp.191-218.

13. Maslach C. Schaufeli WB, Leiter MP. Job burnout / C.Maslach, W.B. Schaufeli, M.P. Leiter // Annual review of psychology. - 2001. - Vol. - Pp.397-422.

14. Maslach $C$. Understanding the burnout experience: recent research and its implications for psychiatry / C.Maslach, M.P. Leiter. - World psychiatry. - 2016. Vol.15. - Issue 2. - Pp.103-111.

15. Schaufeli W. B. Burnout: 35 years of research and practice / W.B. Schaufeli, M.P. Leiter, C.Maslach // Career develop international. - 2009. - Vol.14. - Issue 3. - Pp.204 -220 .

\section{References (Transliteration):}

1. Kratkij psihologicheskij slovar' / Pod obshh. red. A.V. Petrovskogo, M.G. Jaroshevskogo; Red.-sost. L.A. Karpenko. - Rostov n/D : Feniks, 1999. - 505 s.

2. Ljengle $A$. Jemocional'noe vygoranie $\mathrm{s}$ pozicii jekzistencial'nogo analiza / A. Ljengle // Voprosy psihologii. - 2008. - № 2. - S.3-16.

3. Metodika diagnostiki urovnja jemocional'nogo vygoranija V.V. Bojko [Jelektronnyj resurs]. - Rezhim dostupa: http://psylist.net/praktikum/19.htm.

4. Minutko $\quad V$. L. Reaktivnaja depressija [Jelektronnyj resurs] / V.L. Minutko. - Rezhim dostupa: http:// www.depressia.com/depressiya/reaktivnaya-depressiya.

5. Orel $V$. E. Sindrom psihicheskogo vygoranija. Mify i real'nost' / V.E. Orel. - H.: Gumanitarnyj centr, 2014. - 296 s.

6. Polenova N. $\quad$. Reaktivnaja depressija: prichiny, simptomy i lechenie jetoj bolezni [Jelektronnyj resurs] / N.V. Polenova. - Rezhim dostupa: http://depressio.ru/ nastroenie/14-reaktivnaya-depressiya.html.

7. Reaktivnaja depressija // Jenciklopedicheskij slovar' po psihologii i pedagogike. 2013 [Jelektronnyj resurs]. - 
Rezhim dostupa: http://psychology_pedagogy. academic.ru/14613/Reaktivnaja_depressija.

8. Reaktivnaja depressija [Jelektronnyj resurs]. - Rezhim dostupa: // http://depressia.info/vidy-depressiy/reaktivnayadepressiya/.

9. Samoukina N. V. Sindrom professional'nogo vygoranija / N.V. Samoukina // Medicinskaja gazeta. - 2005. - № 43. 8 ijulja. - S.21-22.

10. Trunov D. G. «Sindrom sgoranija»: pozitivnyj podhod k probleme / D.G. Trunov // Zhurnal prakticheskogo psihologa. - 1998. - № 8. - S.84-89.

11. Trunov D. G. Eshhe raz o «sindrome sgoranija»: jekzistencial'nyj podhod [Jelektronnyj resurs] / D.G. Trunov. - Rezhim dostupa: http://hpsy.ru/public/x833.htm.

12. Maslach C. Maslach burnout inventory manual / C.Maslach, S.E. Jackson, M.P. Leiter // Zalaquett C.P., Wood R.J. Evaluating stress: a book of resources. Lanham, Maryland: Scarecrow Press, 1997. - Pp.191-218.

13. Maslach C. Schaufeli WB, Leiter MP. Job burnout / C.Maslach, W.B. Schaufeli, M.P. Leiter // Annual review of psychology. - 2001. - Vol. - Pp.397-422.

14. Maslach $C$. Understanding the burnout experience: recent research and its implications for psychiatry / C.Maslach, M.P. Leiter. - World psychiatry. - 2016. Vol.15. - Issue 2. - Pp.103-111.

15. Schaufeli $W$. B. Burnout: 35 years of research and practice / W.B. Schaufeli, M.P. Leiter, C.Maslach // Career develop international. - 2009. - Vol.14. - Issue 3. Pp..204-220.

\section{Proskurnyak Olha}

Candidate of psychological sciences, associate Professor of psychology department, Yuriy Fedkovych Chernivtsi National University, Chernivtsi (Ukraine)

\section{Chaplak Yan}

Candidate of psychological sciences, associate Professor of psychology department, Yuriy Fedkovych Chernivtsi National University, Chernivtsi (Ukraine)

\section{Chuyko Halyna}

Candidate of philological sciences, associate Pro-fessor of psychology department, Yuriy Fedkovych Chernivtsi National University, Chernivtsi (Ukraine)

\section{THE EXPERIENCE OF EMOTIONAL BURNOUT AND DEPRESSION IN A STUDENT'S AGE}

\section{ABSTRACT}

The theoretical analysis of the emotional burnout and depression and an empirical study of their interconnection were carried out in the article.

The history of burnout study in psychology, from the time of its appearance and interpretation was briefly followed up.

It is revealed that emotional burnout is often understood as a mechanism of psychological protection in the form of reduction of emotional experiences in response to the psychotraumatic influence or the response of chronic stress when energetic capacities and psychophysical resources of a person are exhausted.

It is shown that the structure of burnout, groups of its symptoms and spheres of human life, the mismatch between which and the functioning of human into them increases the probability of his burnout were distinguished in psychology.

It is noted that scientists pay special attention to the experience of depression among the symptoms of the process of emotional burnout; the main differences between these phenomena and understanding of the depressive state as a re- 
action to the psycho-traumatic situation and its manifestations and symptoms in psychology were determined.

It was indicated that different situations that sharply violate the course of human life, destroying its life goals, values and meaning, are personally significant can cause reactive depression.

It is concluded that the simultaneous manifestation of emotional burnout and depression in a person is not the evidence of a causal relationship between them, but correlation between them exists; that the experience of the emotional burnout and / or depression by person is connected with certain personal characteristics, peculiarities of self-attitude, locus of control and perception of life.

Key words: burnout, reactive depression, stress, emotional exhaustion, depersonalization, reduction of professional accomplishments.

\section{Проскурняк Ольга Петровна}

Кандидат психологических наук, доиент кафедры психологии Черновецкого национального университета имени Юрия Федьковича, г. Черновиьь (Украина)

\section{Чаплак Ян Васильевич}

Кандидат психологических наук, доиент кафедры психологии Черновецкого национального университета имени Юрия Федьковича, г. Черновиьь (Украина)

\section{Чуйко Галина Васильевна}

Кандидат филологических наук, дочент кафедры психологии Черновецкого национального университета имени Юрия Федьковича, г. Черновцьь (Украина)

\section{ПЕРЕЖИВАНИЕ ЭМОЦИОНАЛЬНОГО ВЫГОРАНИЯ И ДЕПРЕССИИ В СТУДЕНЧЕСКОМ ВОЗРАСТЕ}

Аннотация. Статья связана с теоретическим анализом и эмпирическим исследованием эмоционального выгорания и депрессивного состояния у студентов-психологов.

Охарактеризованы основные симптомы, причины и факторы развития данных аффективных проявлений; указано, что их основной причиной ученые считают длительный стресс или влияние на человека психотравмирующих ситуаций.

Сделан вывод, что между выгоранием и переживанием реактивной депрессии существуют различия, что, несмотря на возможность одновременного проявления эмоционального выгорания и депрессивного состояния у человека, причинно-следственная связь между этими феноменами не выявлена.

Ключевые слова: выгорание, реактивная депрессия, стресс, эмоциональное истощение, деперсонализация, редукция персональных достижений. 